\title{
Study the Effect of Different Irrigation and Fertigation Levels on Growth and Yield Parameters of Cucumber crop under Naturally Ventilated Polyhouse
}

\author{
Akanksha Shukla ${ }^{1 *}$ S. R. Bhakar ${ }^{1}$, B. G. Chippa ${ }^{2}$ and Manjeet Singh ${ }^{2}$ \\ ${ }^{1}$ Department of Soil and Water Engineering, C.T.A.E, MPUAT, Udaipur-313001, \\ Rajasthan, India \\ ${ }^{2}$ Department of horticulture, RCA, MPUAT, Udaipur-313001, Rajasthan, India \\ *Corresponding author
}

\section{A B S T R A C T}

\section{Keywords \\ Cucumber crop, Naturally Ventilated Polyhouse}

\section{Article Info}

Accepted: 26 September 2020 Available Online: 10 October 2020
The field experimental study was carried out under naturally ventilated polyhouse during rainy season at Technology park of CTAE, Udaipur to study the influence of irrigation and fertigation level on growth and yield attributes of cucumber. The experiment consisted of 9 treatment combination with 3 replications in randomized block design. The treatments include 3 irrigation levels viz. $100 \%, 80 \%$ and $60 \%$ ET through drip and 3 levels of fertilizer application viz. $120 \%, 100 \%, 80 \%$ RDF of NPK through fertigation. The effects of different treatments recorded the significant effect on growth and yield attributes of cucumber. Maximum average plant height $(365.07 \mathrm{~cm})$, maximum number of leaves per plant (39.8), days to 50\% flowering (30.67), days to first harvest (42.67), average length of fruit $(14.88 \mathrm{~cm})$, average diameter of fruit $\left(3.71 \mathrm{~cm}\right.$ )were reported in treatment $\mathrm{T}_{5}$ (drip irrigation with $80 \%$ ETc and fertigation at $100 \%$ RDF) as compared to other treatments. However maximum individual weight of fruit (130.98 gm), number of fruits per plant (23.40), Maximum yield of fruit (158.28tonnes/ha) were observed in $\mathrm{T}_{5}$ treatment respectively. By considering all the aspects treatment $\mathrm{T}_{5}$ was observed best among all other treatments.

\section{Introduction}

In nutritional welfare, economic viability, vegetables play a vital role and fit well into the main intensive crop system in various parts of our world. In our country vegetable production is consciously predisposed by the conditions of seasonality and temperature. It is primarily India's extensively grown warm season crop and can be closely incorporated into vegetable and non-vegetable crop rotation. It has huge potential for generating yield, revenue, and service per area and time unit.

The cucumber (Cucumis sativus L.) is one of the most favored vegetables grown in tropical and subtropical areas, where it is grown both in the field and under protected conditions. This crop belonging to the cucurbitaceae family is commonly referred to as cucurbits. A wide variety of vegetables used either for 
salad (cucumber) or cooking (all gourds), pickling (western Indian Serkin) or as desert fruits (musk melon, water melon) or candied or preserved (ash gourd). The Cucurbitaceace family found melons, gourds, tomato, squashes and cucumber to be a wide variety of vegetables. Cucumber is one of the oldest grown vegetable crops possibly originating in India. Cucumber is an incredibly low-calorie food, containing just 15 calories per $100 \mathrm{~g}$. It contains high content of water which makes cucumber an ideal food for hydration and cooling. This is a very good source of potassium, vitamin $\mathrm{K}$ and other special antioxidants that are essential for the human body's brain, heart and urinary system (Sikarwar, 2016). The region under cultivation and cucumber production in India during 2016-2017, 2017-2018 was 78000, 72000 ha and 1142, 1260 M Tonnes, respectively (A glance horticultural statistics, 2018). Per ha kheera productivity In India as well as in all parts of Rajasthan is lower than developed countries and emerging countries.

It is becoming increasingly necessary to use water effectively as irrigation. Water application method such as drip can make a significant contribution to making the best use of water for agriculture which improves irrigation efficiency. Drip irrigation is one of the technologies used to add on-farm water to maximize the crop water. Under protected cultivation higher water and nutrient efficiencies can be achieved. Proper management of nutrients and water are important parameters of safe cultivation (Bhattarai et al., 2015). This has become an attractive fertigation process in modern intensive agriculture due to the higher water and fertilizer application capacity of the drip irrigation and ease of use in all-weather conditions.

Fertigation is the application of water-soluble solid fertiliser applied through drip irrigation directly to the root zone plant. It increases the fertilizer efficiency by saving fertilizer. In polyhouse technique yield of crop increased but proper water and fertiliser management will be necessary. The present work was conducted to study the effect of irrigation and fertigation levels on growth and yield of cucumber crop under NVP in order to find out best combination of water and fertilizer treatment.

\section{Materials and Methods}

The present research work was conducted inside the naturally ventilated polyhouse during rainy season of 2019-20at Technology Park of CTAE, Maharana Pratap University of Agriculture and Technology, Udaipur. Nine treatments combination were applied in Randomized Block Design with three replications. The treatments consist of 3 levels of irrigation. viz. $100 \% \mathrm{ET}_{\mathrm{C}}\left(\mathrm{I}_{1}\right), 80 \% \mathrm{ET}_{\mathrm{C}}\left(\mathrm{I}_{2}\right)$, $60 \% \mathrm{ET}_{\mathrm{C}}\left(\mathrm{I}_{3}\right)$, through drip irrigation and 3 level of fertigation, $120 \%$ RDF $\left(\mathrm{F}_{1}\right), 100 \%$ $\operatorname{RDF}\left(\mathrm{F}_{2}\right), 80 \% \operatorname{RDF}\left(\mathrm{F}_{3}\right)$ through drip.

\section{Estimation of Reference Crop}

\section{Evapotranspiration $\left(\mathbf{E T}_{\mathbf{0}}\right)$}

The daily reference crop evapotranspiration was estimated by using the standard method i.e. FAO Penman-Monteith (Allen et al., 1998)

\section{Crop evapotranspiration}

The daily crop evapotranspiration was estimated using Equation as shown below:

$\mathrm{ET}_{\mathrm{C}}=\mathrm{K}_{\mathrm{C}} \times \mathrm{ET}_{0}$

Where, $\mathrm{ET}_{\mathrm{c}}=$ crop evapotranspiration, $(\mathrm{mm} /$ day $), \mathrm{K}_{\mathrm{c}}=$ crop coefficient, $\mathrm{ET}_{0}=$ Reference Crop Evapotranspiration, (mm/day) 
The volume of water required under drip irrigation system was computed by following formula.

$\mathbf{W}_{\mathbf{r}}=\frac{\text { Crop area } \times \mathrm{ET}_{0} \times \mathrm{K}_{\mathrm{C}} \times \mathrm{W}_{\mathbf{2}}}{\mathbf{E}_{\mathrm{u}}}$

Where, $\mathrm{W}_{\mathrm{r}}=$ peak water requirement, (lit/day/plant), Crop area $=$ row to row $\operatorname{spacing}(\mathrm{m}) \times$ plant to plant spacing $(\mathrm{m})$ of the crop, $\mathrm{ET}_{0}=$ reference evapotranspiration, $(\mathrm{mm} /$ day $), \mathrm{K}_{\mathrm{C}}=$ crop coefficient, $\mathrm{Wa}=$ wetted area, $(\%)$.

Mini Angel F1 hybrid cucumber was sown under naturally ventilated polyhouse on $10^{\text {th }}$ July 2019 with 2 rows per plot consisting of 30plants/plot. Keeping row to row, plant to plant distance $50 \mathrm{~cm} \times 50 \mathrm{~cm}$ respectively. Total2 7 lateral was used for experimental set up. Each lateral served one row with in-line emitter distance at $30 \mathrm{~cm}$ and discharge rate of 2 lit per hour.

Irrigation scheduling has been decided before growing of the crop by using the last five years data i.e. 2014-15 to 2018-19 for the months July to October. Available capacity of tank was 1000 lit, so for convenient basis, water was supplied after total depletion of 1000 lit water. Mean water was applied with 2 to 3 days interval according to the treatments. Scheduling of fertilizer was done by Full dose of $\mathrm{P}$, half dose of $\mathrm{N}$ and $\mathrm{K}$ applied as basal dose and remaining half dose of $\mathrm{N}, \mathrm{K}$ was applied through fertigation after 30 DAS in 6days interval into 3 fertigation levels $120 \%$ RDF, $100 \%$ RDF, $80 \%$ RDF. All other packages, input sources and practices were adopted same to all treatment as recommended for the region.

The water use efficiency was determined by following equation:

WUE $=\frac{\mathrm{Y}}{\mathrm{WR}}$
Where, WUE = Water Use Efficiency, $\left(\mathrm{kg} / \mathrm{m}^{3}\right), \mathrm{Y}=$ Crop yield, $(\mathrm{kg} / \mathrm{ha}), \mathrm{WR}=$ water requirement, $\left(\mathrm{m}^{3} / \mathrm{ha}\right)$.

The fertilizer use efficiency was computed by the following equation.

FUE $=\frac{\text { Crop Yield }(\mathrm{kg} / \mathrm{ha})}{\text { Total quantity of nutrient applied }(\mathrm{kg} / \mathrm{ha})}$...(4)

Statistical analysis of data was performed using a randomized block design with three replications. 5\% level of significance was considered in ANOVA to test the influence of different irrigation and fertigation levels on growth and yield attributes of cucumber.

\section{Results and Discussion}

The performance evaluation of drip irrigation system was studied before conducting the experiment. The drip system performed at emission uniformity of $85.93 \%$ with $1.76 \mathrm{lph}$ average discharge rate indicating the good performance of the system. Physio-chemical properties of soil were also determined. Actual water required for cucumber crop was determined by penman Monteith equation using daily climatic data under NVPH during season 2019-20. According to thistotal51 times 1000 lit of irrigation water was supplied to crop as per the different treatments i.e. 100 $\% \mathrm{ET}_{\mathrm{C}}, 80 \% \mathrm{ET}_{\mathrm{C}}$ and $60 \% \mathrm{ET}_{\mathrm{C}}$. Total water requirement of cucumber crop under NPVH at $100 \% \mathrm{ET}_{\mathrm{C}}$ (i.e. $\mathrm{T}_{1}, \mathrm{~T}_{2}, \mathrm{~T}_{3}$ ), $80 \% \mathrm{ET}_{\mathrm{C}}$ (i.e. $\left.\mathrm{T}_{3}, \mathrm{~T}_{4}, \mathrm{~T}_{5}\right)$ and $60 \% \mathrm{ET}_{\mathrm{C}}\left(\mathrm{i} . \mathrm{eT}_{6}, \mathrm{~T}_{7}, \mathrm{~T}_{8}\right.$ ) was $275.21,220.17$ and $165.12 \mathrm{~mm}$ respectively.

\section{Growth parameters of cucumber crop}

\section{Plant height}

At 30 DAS, 45 DAS, 90 DAS and last harvest plant height was observed maximum (155.33, 204.07, 351.87 and $365.07 \mathrm{~cm})$ in $\mathrm{T}_{5}$ treatment followed by $\mathrm{T}_{4}(155.33,201.40$, 
350.27 and $363.47 \mathrm{~cm}$ ), which is significantly higher than other 8 treatments and lower with $\mathrm{T}_{9}(146.13,186.60,336.40$ and $349.60 \mathrm{~cm})$ respectively. At 60 DAS, plant height was observed maximum $(269.07 \mathrm{~cm})$ in $\mathrm{T}_{5}$ followed by $\mathrm{T}_{3}(266.40 \mathrm{~cm})$. The result showed that there is a less significant difference between $\mathrm{T}_{4}$ and $\mathrm{T}_{5}$ treatment. The minimum plant height $(251.60 \mathrm{~cm})$ was recorded in $\mathrm{T}_{9}$ treatment at 60 DAS respectively.

Combined irrigation and fertilization effect, $\mathrm{T}_{5}$ (drip irrigation with 80 per cent $\mathrm{ET}_{\mathrm{C}}$ and 100 per cent RDF fertilization) recorded significantly higher plant height than the rest of the combinations. This could be because of the optimum nutrient and moisture availability. The higher irrigation level i.e.100 percent $\mathrm{ET}_{\mathrm{C}}$ may have leaching down from the root zone of the available nutrients. This result is similar to the result reported by Pawar et al., (2018) for the cucumber crop. Similarly, Chand (2014), Shinde et al., (2010) recorded a higher height of NPK 's 100 percent RDF through fertigation. Rahil and Qanadillo (2015) reported the highest plant height of the cucumbers at $75 \mathrm{ET}_{\mathrm{C}}$.

\section{Number of leaves per plant}

At 30 DAS, 45 DAS, 60 DAS, 90 DAS and last harvest number of leaves per plant was observed maximum $(18.00,23.20,29.60$, 38.00 and 39.80) in $\mathrm{T}_{5}$ treatment followed by $\mathrm{T}_{4}$ (17.47, 22.67, 29.07, 37.47 and 39.27), which is significantly higher than other 8 treatments and lower with $\mathrm{T}_{9}(15.27,20.47$, 26.87, 35.27 and 37.07) respectively. The result showed that there is a less significant difference between $T_{4}$ and $T_{5}$ treatment.

Combined effect of irrigation and fertigation, $\mathrm{T}_{5}$ (drip irrigation with $80 \% \quad \mathrm{ET}_{\mathrm{C}}$ and fertigation at $100 \%$ RDF) registered significantly higher number of leaves than rest of the combinations. This might be due to the optimum availability of nutrients and moisture. The higher level of irrigation i.e.100\% $\mathrm{ET}_{\mathrm{C}}$ may have leach down the available nutrients from the root zone.

\section{Days to $50 \%$ flowering and days to first harvest}

Days to $50 \%$ flowering was significantly influenced by effect of irrigation and fertigation level as shown in Table 1 . Minimum days required for $50 \%$ flowering was reported in treatment $\mathrm{T}_{5}$ (30.67) followed by treatment $\mathrm{T} 4$ (31.67). Maximum days required for $50 \%$ flowering was reported in $\mathrm{T}_{9}$ (36.67).Treatment $\mathrm{T}_{9}$ (drip irrigation with $60 \% \mathrm{ETc}$ and fertigation at $80 \% \mathrm{RDF}$ ) prolonged the vegetative growth so that late flowering occurred at $T_{9}$.

Minimum days required for first harvest was reported in treatment $T_{5}(42.67)$ at par with treatment $T_{4}$ (43.33) and superior to all other treatments. This might be due to very favorable combination of irrigation $(80 \%$ $\left.\mathrm{ET}_{\mathrm{C}}\right)$ and fertigation level (100\% RDF of NPK). Maximum days required for first harvest was reported in $\mathrm{T}_{9}$ (48.33).

It might be attributed to low level of drip irrigation with low level of fertigation. It prolongs the vegetative growth of cucumber plant and delayed maturity.

\section{Length and diameter of cucumber}

The length of the cucumber fruit after yield picking was measured using Vernier calipers and determined average length of the fruit for different treatments. As shown in Table 1, the average fruit duration was significantly affected by irrigation effect and fertigation stage. Maximum length of fruit was reported in treatment $\mathrm{T}_{5}$ (drip irrigation with $80 \%$ ETc and fertigation at $100 \% \mathrm{RDF}$ ) i.e. $14.88 \mathrm{~cm}$ 
followed by $\mathrm{T}_{4}(14.87 \mathrm{~cm})$. Similar to the result obtained by Pawar et al., (2018).

Maximum average length of fruit and average diameter of the fruit were reported in treatment $\mathrm{T}_{5}$ (drip irrigation with $80 \%$ ETc and fertigation at $100 \% \mathrm{RDF}$ ) i.e. $14.88 \mathrm{~cm}$ and $3.71 \mathrm{cmand}$ followed by $\mathrm{T}_{4}(14.87 \mathrm{~cm}$ and $3.67 \mathrm{~cm}$ ) respectively (Table 2). Minimum length of fruit and diameter of fruit was reported in $\mathrm{T}_{9}(13.65 \mathrm{~cm}$ and $3.34 \mathrm{~cm})$ respectively.

It might be due to optimum availability of water and nutrient without loss of fertiliser increases photosynthesis. Also might be due to higher nutrient uptake by plant at drip irrigation with $80 \%$ ETc and fertigation at $100 \%$ RDF.Similar to the result obtained by Pawar et al., (2018). Patil and Gadge (2016) reported the maximum average diameter of the cucumber fruit was observed with application of 100 per cent $\mathrm{N}$ through drip and soil application of $\mathrm{P}$ and $\mathrm{K}$ i.e. $\mathrm{T} 2$ (3.89 $\mathrm{cm})$.

\section{Yield parameter individual fruit weight}

The data regarding to individual weight of fruit are presented in Table 2. Individual weight of fruit was affected significantly due to combined effect of irrigation and fertigation levels. The fruit weight plays an important role in increasing the total yield in cucumber. However, the individual fruit weight (130.98 gm) was recorded in treatment $\mathrm{T}_{5}$ followed by $\mathrm{T}_{4}(126.62 \mathrm{gm})$ which was significantly superior over the all other treatments. This was largely due to the increased length and diameter of fruit. This could be due to a high uptake of nutrients and build-up of sufficient photosynthesis enabling the increase in size of fruits (length and diameter), resulting in the increased fruit weight and its volume. The lowest individual fruit weight $(118.17 \mathrm{gm})$ was recorded in treatment $\mathrm{T}_{9}$.

Table.1 Effect of different irrigation and fertigation levels on growth Parameter of cucumber plant

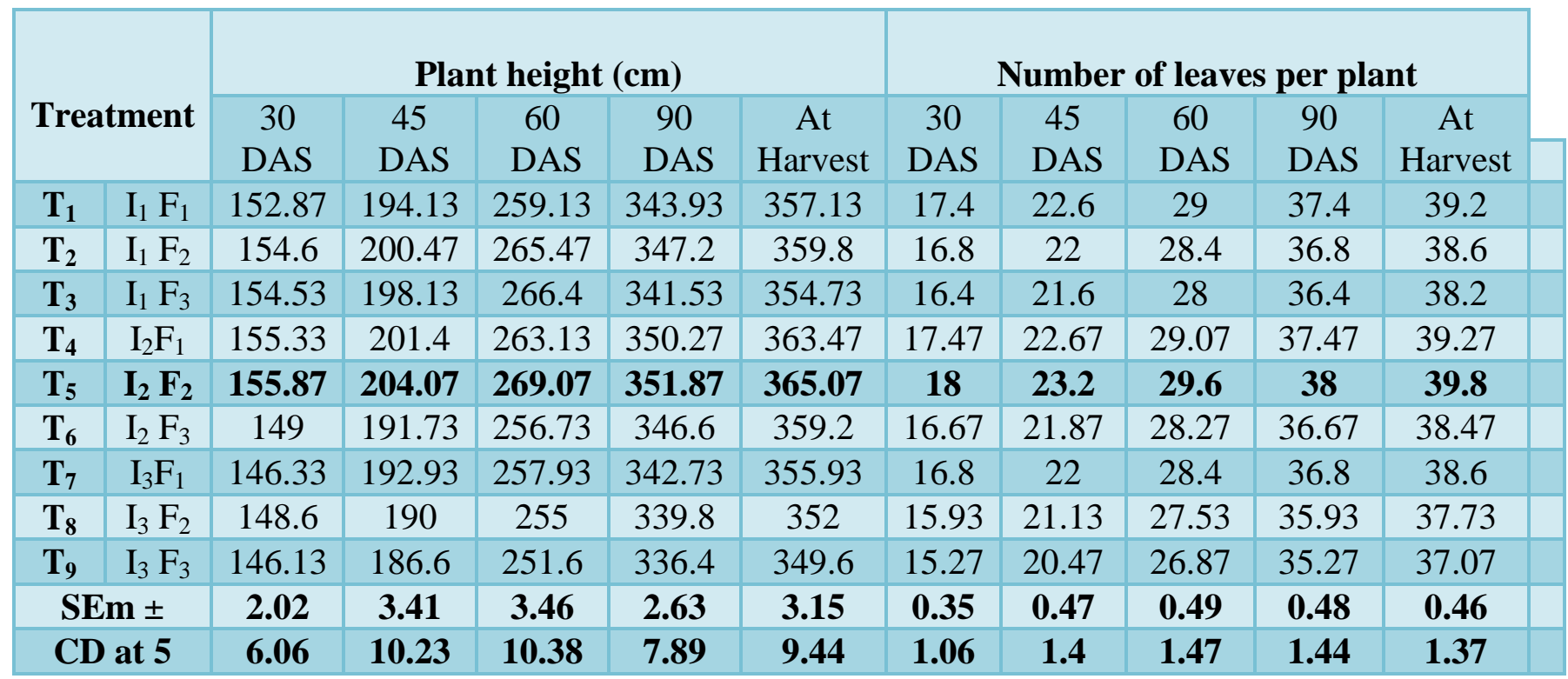


Table.2 Effect of different irrigation and fertigation levels on growth Parameter of cucumber plant

\begin{tabular}{|c|c|c|c|c|c|}
\hline \multicolumn{2}{|c|}{ Treatment } & $\begin{array}{c}\text { Days for 50\% } \\
\text { flowering }\end{array}$ & $\begin{array}{c}\text { Days to first } \\
\text { harvest }\end{array}$ & $\begin{array}{c}\text { Length of fruit } \\
(\mathbf{c m})\end{array}$ & Dia. of fruit $(\mathbf{c m})$ \\
\hline $\mathbf{T}_{\mathbf{1}}$ & $\mathrm{I}_{1} \mathrm{~F}_{1}$ & 32 & 44.67 & 14.82 & 3.57 \\
\hline $\mathbf{T}_{\mathbf{2}}$ & $\mathrm{I}_{1} \mathrm{~F}_{2}$ & 31.67 & 45.33 & 14.85 & 3.66 \\
\hline $\mathbf{T}_{\mathbf{3}}$ & $\mathrm{I}_{1} \mathrm{~F}_{3}$ & 34.33 & 47 & 14.74 & 3.61 \\
\hline $\mathbf{T}_{\mathbf{4}}$ & $\mathrm{I}_{2} \mathrm{~F}_{1}$ & 31.67 & 43.33 & 14.87 & 3.67 \\
\hline $\mathbf{T}_{\mathbf{5}}$ & $\mathrm{I}_{2} \mathrm{~F}_{2}$ & $\mathbf{3 0 . 6 7}$ & $\mathbf{4 2 . 6 7}$ & $\mathbf{1 4 . 8 8}$ & $\mathbf{3 . 7 1}$ \\
\hline $\mathbf{T}_{\mathbf{6}}$ & $\mathrm{I}_{2} \mathrm{~F}_{3}$ & 34.33 & 46.67 & 14.81 & 3.54 \\
\hline $\mathbf{T}_{\mathbf{7}}$ & $\mathrm{I}_{3} \mathrm{~F}_{1}$ & 35.33 & 46.67 & 14.47 & 3.51 \\
\hline $\mathbf{T}_{\mathbf{8}}$ & $\mathrm{I}_{3} \mathrm{~F}_{2}$ & 36 & 48 & 14.25 & 3.34 \\
\hline $\mathbf{T}_{\mathbf{9}}$ & $\mathrm{I}_{3} \mathrm{~F}_{3}$ & 36.67 & 48.33 & 13.65 & 3.39 \\
\hline \multicolumn{2}{|c|}{$\mathbf{S E m} \pm$} & $\mathbf{0 . 4 8}$ & $\mathbf{0 . 4 6}$ & $\mathbf{0 . 1}$ & $\mathbf{0 . 4 8}$ \\
\hline \multicolumn{2}{c}{$\mathbf{C D}$ at $\mathbf{5}$} & $\mathbf{1 . 4 4}$ & $\mathbf{1 . 3 8}$ & $\mathbf{0 . 3}$ & $\mathbf{1 . 4 3}$ \\
\hline
\end{tabular}

Table.3 Effect of different irrigation and fertigation levels on yield attributes of cucumber plant

\begin{tabular}{|c|c|c|c|c|c|c|c|}
\hline \multicolumn{2}{|c|}{ Treatment } & $\begin{array}{l}\text { Individual weight } \\
\text { of fruit (gm) }\end{array}$ & $\begin{array}{l}\text { No. of fruit } \\
\text { per plant }\end{array}$ & $\begin{array}{l}\text { Weight of fruits } \\
\text { /plant (kg) }\end{array}$ & $\begin{array}{l}\text { Yield / } \\
\text { plot (kg) }\end{array}$ & $\begin{array}{c}\text { Yield / sq.m } \\
\text { Kg/sq. m }\end{array}$ & $\begin{array}{c}\text { Yield } \\
\text { (ton/ha) }\end{array}$ \\
\hline$T_{1}$ & $\mathrm{I}_{1} \mathrm{~F}_{1}$ & 125.78 & 20.8 & 2.53 & 73.77 & 13.17 & 131.74 \\
\hline $\mathbf{T}_{2}$ & $\mathrm{I}_{1} \mathrm{~F}_{2}$ & 124.78 & 20.4 & 2.59 & 77.75 & 13.88 & 138.84 \\
\hline $\mathbf{T}_{3}$ & $\mathrm{I}_{1} \mathrm{~F}_{3}$ & 122.67 & 19.93 & 2.46 & 76.02 & 13.58 & 135.75 \\
\hline $\mathbf{T}_{4}$ & $\mathrm{I}_{2} \mathrm{~F}_{1}$ & 126.62 & 21.07 & 2.6 & 78.09 & 13.94 & 139.44 \\
\hline$T_{5}$ & $\mathrm{I}_{2} \mathrm{~F}_{2}$ & 130.98 & 23.4 & 2.95 & 88.63 & 15.83 & 158.28 \\
\hline$T_{6}$ & $\mathrm{I}_{2} \mathrm{~F}_{3}$ & 121.49 & 20 & 2.36 & 70.67 & 12.62 & 126.19 \\
\hline $\mathbf{T}_{7}$ & $\mathrm{I}_{3} \mathrm{~F}_{1}$ & 121.48 & 18 & 2.35 & 70.42 & 12.58 & 125.75 \\
\hline $\mathbf{T}_{8}$ & $\mathrm{I}_{3} \mathrm{~F}_{2}$ & 118.69 & 17.8 & 2.1 & 63.08 & 11.26 & 112.64 \\
\hline$T_{9}$ & $\mathrm{I}_{3} \mathrm{~F}_{3}$ & 118.17 & 16.13 & 1.96 & 58.68 & 10.48 & 104.79 \\
\hline \multicolumn{2}{|c|}{$\mathrm{SEm} \pm$} & 2.47 & 0.25 & 0.1 & 0.6 & 3.63 & 6.393 \\
\hline \multicolumn{2}{|c|}{ CD at 5} & 7.4 & 0.75 & 0.3 & 1.79 & 10.88 & 19.167 \\
\hline
\end{tabular}

Fig.1 Water use efficiency (WUE) of cucumber in different treatments

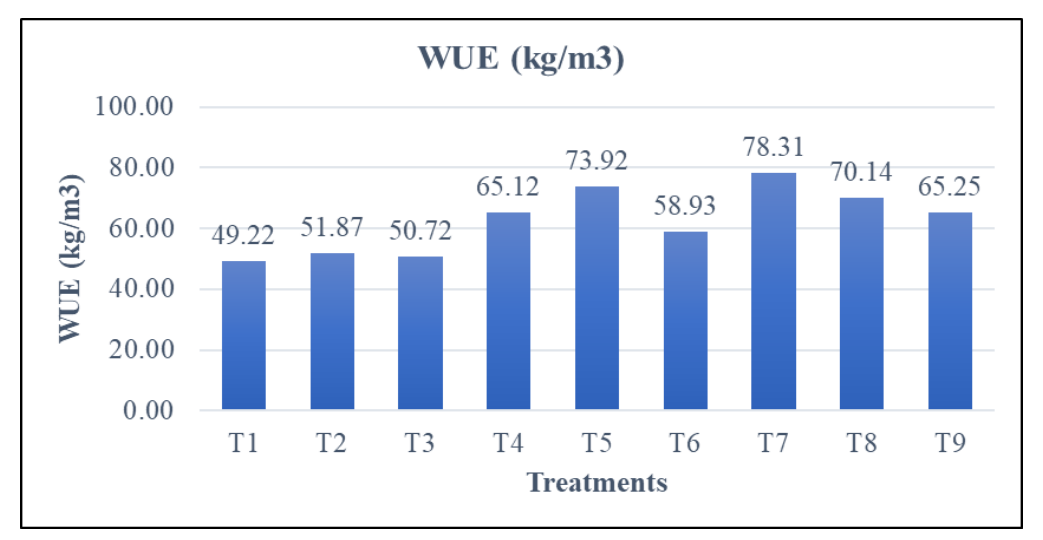


Fig.2 Fertilizer use efficiency (FUE) of cucumber in different treatments

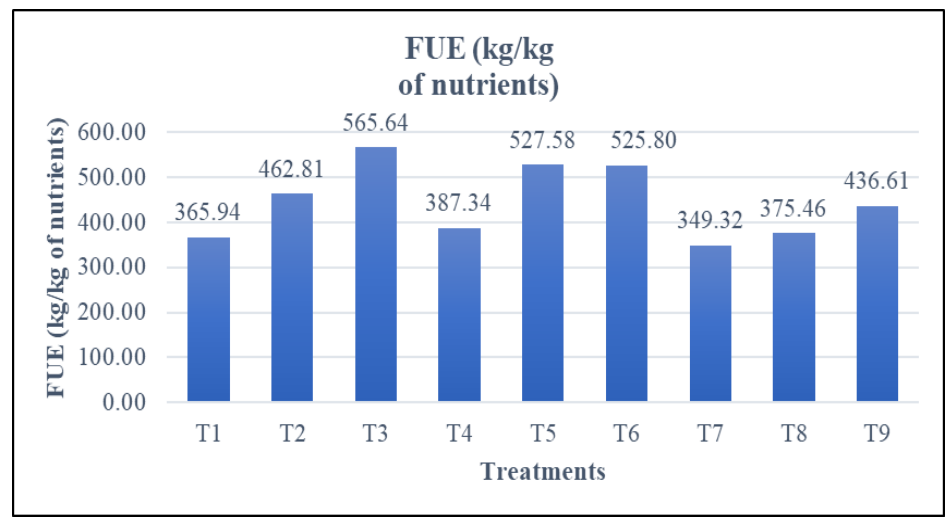

\section{No. of fruits per plant}

Maximum no. of fruit per plant was obtained in $\mathrm{T}_{5}$ (23.40) followed by $\mathrm{T}_{4}$ treatment (20.80). This result shown that at $80 \% \mathrm{ET}_{\mathrm{C}}$ with $100 \%$ and $120 \%$ RDF of NPK due to favourable condition more aeration, sufficient moisture and high uptake of nutrient as compared to other treatment, enhanced vegetative growth. Plant height obtained in $\mathrm{T}_{5}$ was higher means higher no. of nodes resulting in higher no. of fruit. Minimum no. of fruit per plant (16.13) was obtained in $\mathrm{T}_{9}$.

Due to inadequate water and low level of fertigation, less plant height. Gupta et al., (2014) reported that in cucumber crop maximum no. of fruit (22) was obtained in treatment combination of $80 \%$ ET through drip $+80 \%$ recommended NPK through fertigations. Also, Pawar et al., (2018) reported that the application of 100 per cent fertilizers through water soluble fertilizer through drip at 80 per cent evaporation in cucumber crop resulted in significantly higher number of fruits per plant (34.80).

\section{Yield of fruit}

The data pertaining to average total weight of fruits per plant and yield of crop as influenced by different irrigation and fertigation levels are presented in Table 3. Maximum weight of fruit per plant, yield per plot $\mathrm{kg}$, yield per sq.m were observed in $\mathrm{T}_{5}$ treatment $(2.95 \mathrm{~kg})$, $(88.63 \mathrm{~kg} / \mathrm{plot}),(15.83 \mathrm{~kg} / \mathrm{sq} . \mathrm{m})$ respectively. Minimum weight of fruit per plant, yield per plot $(\mathrm{kg})$, yield per sq.m, were observed in $\mathrm{T}_{9}$ treatment $(1.96 \mathrm{~kg}),(58.68 \mathrm{~kg} / \mathrm{plot}),(10.48$ $\mathrm{kg} / \mathrm{sq} . \mathrm{m}$ ) respectively.

Table 3 shown that maximum yield of cucumber per hectare was obtained in $\mathrm{T}_{5}$ treatment (158.28 tonnes per ha) followed by $\mathrm{T}_{4}$ treatment (139.44 tonnes per ha). This result might be due to maximum no. of plant, higher individual weight of fruit obtained in $\mathrm{T}_{5}$ treatment. This might be attributed due to favourable combination of moisture and nutrient available to crop enhanced vegetative and yield growth.

Lower yield (104.79 tonnes per ha) was recorded in $T_{9}$ treatments due to lesser uptake of nutrient by the crop under low level of irrigation and fertigation level. Pawar et al., (2018) reported that treatment combination of $80 \%$ ET through the drip $+100 \%$ RDF of NPK through fertigation produced maximum yield $132.62 \mathrm{t} / \mathrm{ha}$.

The observations were recorded on WUE, FUE, various growth parameters, yield parameters of cucumber and were subjected to statistical analysis. The results regarding to this are discussed as follows: 


\section{Water use efficiency}

Water use efficiency was significantly improved by interactive effect of different irrigation and fertigation level (Fig.1). The result of study indicated that water use efficiency increased by reduction in irrigation water applied through drip with higher level of fertigation. Highest WUE $\left(78.31 \mathrm{~kg} / \mathrm{m}^{3}\right)$ was realized for $\mathrm{T}_{7}$ treatment (drip irrigation with $60 \%$ ETc and fertigation at $120 \%$ RDF) because this treatment consumed less water with higher level of fertigation. Lowest WUE $\left(49.22 \mathrm{~kg} / \mathrm{m}^{3}\right)$ was obtained under $\mathrm{T}_{1}$ treatment (drip irrigation with 60\% ETc and fertigation at $120 \% \mathrm{RDF}$ ) due to more water applied as compare to other treatments. But at $\mathrm{T}_{5}$ treatment, WUE $\left(73.92 \mathrm{~kg} / \mathrm{m}^{3}\right)$ was observed with comparatively higher yield. This result are also agreement with (Dunage et al., 2008), (Soni 2013) and (Joshi 2014). (Pawar et al., (2018) was reported that $60 \% \mathrm{ET}_{\mathrm{C}}$ treatments has higher WUE $\left(62.33 \mathrm{~kg} / \mathrm{m}^{3}\right)$ of cucumber crop than other treatments under green house cultivation). (Wang and Xing 2016) researcher reported that in tomato crop highest WUE is obtained in the W3F1 (W3-50\% $\mathrm{ET}_{\mathrm{C}}, \mathrm{F} 1-\mathrm{N}-240-\mathrm{P}_{2} \mathrm{O}_{5}-$ $120-\mathrm{K}_{2} \mathrm{O}-150 \mathrm{Kg} / \mathrm{ha}$ ) treatment in tomato crop and was $45 \mathrm{~kg} / \mathrm{m}^{3}$ and $47.7 \mathrm{~kg} / \mathrm{m}^{3}$ in 2012 and 2013 , respectively.

\section{Fertilizer use efficiency}

The fertilizer use efficiency as influenced by irrigation and fertilizer levels was depicted in Fig.2. The FUE has decreased with increase in level of fertilizer in all the treatment. It is seen from the Fig.2 that the highest fertilizer use efficiency recorded was $565.64 \mathrm{~kg}$ of yield $/ \mathrm{kg}$ of nutrients applied in Treatment $\mathrm{T}_{3}$ (drip irrigation with $100 \% \mathrm{ETc}$ and fertigation at $80 \%$ RDF). It might be attributed to reduction in quantity of nutrient applied in this treatment and no leaching of nutrients in the form of runoff. Also might be due to efficient use of water $\left(100 \% \mathrm{ET}_{\mathrm{C}}\right)$ increase nutrient uptake by the plant, corresponded with lower fertilizer applied. The researcher (Soni 2013), (Rajak 2015), (Joshi 2014) and (Pawar et al., 2018) stated that at Low level of fertigation FUE is higher.

In conclusion the result of study showed that combination of different irrigation and fertigation levels have significant effect on WUE, FUE, growth and yield attributes of cucumber. The result concluded that WUE increased with reduction in water applied and FUE was enhanced with decreasing quantity of fertilizer applied. There is no significant relation between yield and WUE.

Vegetative growth, was enhanced Due to sufficient moisture availability and higher nutrient uptake by the plant, so increases photosynthesis and cell resulted into more yield. This study concluded that $80 \%$ ETc significantly increases cucumber yieldthan 100 $\%$ ETc at $100 \%$ RDF fertigation. By considering all the aspects such as growth and yield parameters, in water scarcity area, treatment $\mathrm{T}_{5}$ (drip irrigation with $80 \%$ ETc and fertigation at $100 \%$ RDF) is best among all other treatments for cucumber crop under naturally ventilated polyhouse in off season in order to get maximum profit.

\section{References}

Allen, R.G., Pereira, L.S., Raes, D. and Smith, M.1998.Cropevapotranspiration guidelines for computing crop water requirements. Irrigation and Drain, Paper no. 56. FAO, Rome.

Anonymous, 2013. TNAU Agritech Portal, Horticulture.

http://agritech.tnau.ac.in/horticulture/horti_veget ables_cucumber.html.

Anonymous, 2018. Horticultural statistics at a glance 2018, GOI Ministry of Agriculture and farmers' welfare, Department of Agriculture, Cooperation and Farmers' welfare, Horticulture Statics Division. GOI 
Controller of Publication. 256: 500-2018.

Anonymous, 2018.Nutritional recommendations for cucumber in open

fields,tunnelsandgreenhouse.

http://www.haifagroup.com/files/Guides/Cucumber.pdf

Bhattarai, P., Kaushik, R.A., Ameta, K.D., Jain,H.K.,Kaushik,M.K.andSharma,F.L.

2015 Effect of plant geometry and fertigation on growth and yield of cherry tomato (Solanum lycopersiconvar. cerasiforme) under zero energy polyhouse conditions Indian J. Hort. 72: 297-301.

Dunage, V.S., Balakrishnan, P. and Patil,M.G. 2008. Water use efficiency and economics of tomato using drip irrigation under nethouse conditions. Karnataka Journal of Agriculture Science. 22: 133-136.

Gao,N.,Liu,Y.,Wu,H.,Zhang,P.,Yu,N.,Zhang, Y., Zou, H., Fan, Q. and Zhang,Y. 2016. Interactive effects of irrigation and nitrogen fertilizer on yield, nitrogen uptake, and recovery of two successive Chinese cabbagecrops as assessed using $15^{\mathrm{N}}$ isotope Scientia Horticulturae 215: 117-125

Gupta, A.J., Chattoo, M.A. and Bhat F.N. 2014. Standardization of drip irrigation and fertigation practices for commercial cultivation of hybrid cucumber under Kashmir conditions. Progressive Horticulture. 46: 343-348.

Joshi, Y.K. 2014. Study of gravity fed drip irrigation system with varied irrigation and fertigation levels in okra. M.Tech thesis submitted to Maharana Pratap University of Agriculture and Technology Udaipur (Rajasthan).

Madhusudhan, L., 2015. Agriculture role on Indian Economy. Business and Economics Journal 6: 176. doi.10.4172/2151-6219.
1000176.

Patil, M. and Gadge, S. B. (2016). Yield response of cucumber (Cucumis sativus L.) to different fertigation levels. Internat. $J$. Agric. Engg., 9: 145-149.

Pawar, D.P., Bhakar, S.R.,Lakhawat, S.S., Kothari, M. and Patil, V., 2018. Interactive Impact of Irrigation and Fertigation Level on Growth and Yield Attributes of Cucumber under Naturally Ventilated Polyhouse. Int.J.Curr.Microbiol.App.Sci. 7: 2604-2612. https://doi.org/10.20546/ijcmas.2018.706.3 08

Rahil, M.H. and Qanadillo, A. 2015. Effects of different irrigation regimes on yield and water use efficiencyof cucumber crop. Agricultural Water Management, 148: 1015

Rajak, D. 2015. Studies on the effect of irrigation and fertigation level on cabbage under gravity fed drip irrigation. Ph.D. thesis submitted to Maharana Pratap University of Agriculture and Technology Udaipur (Rajasthan).

Sikarwar, P. and Hardaha, M.K. 2016. Effect of fertigation levels on growth, quality and yield of polyhouse cucumber (Cucumis sativus). International Journal of Agriculture Sciences 8: 1863-1866.

Soni, K. 2013.A study on drip irrigation and fertigation of tomato (Lycopersicon esculentum) crop inch hindwara district of (M.P.). M. Tech thesis submitted to the Jawaharlal Nehru Krishi Vishwa Vidyalaya, Jabalpur.

Wang, X. and Xing Y. 2016. Evaluation of the Effect of Irrigation and Fertilization by Drip Fertigation on Tomato Yield and Water Use Efficiency in Greenhouse. International Journal of Agronomy:1-10.

\section{How to cite this article:}

Akanksha Shukla' S. R. Bhakar, B. G. Chippa and Manjeet Singh. 2020. Study the Effect of Different Irrigation and Fertigation Levels on Growth and Yield Parameters of Cucumber crop under Naturally Ventilated Polyhouse. Int.J.Curr.Microbiol.App.Sci. 9(10): 3730-3738. doi: https://doi.org/10.20546/ijcmas.2020.910.429 